\title{
PLATELET-RICH AUTOPLAZMA EFFECT ON INTESTINAL ANASTOMOSIS REGENERATION IN RABBITS
}

\author{
BERIK NURADDINOVICH DZHUMABEKOV ${ }^{1}$, AUYESKHAN TULEGENOVICH DZHUMABEKOV ${ }^{1}$, \\ DZHUMAGALY KAZYBAEVICH ISMAILOV ${ }^{1}$, TALGAT ALISHOVICH BAITILEUOV ${ }^{2}$ \\ and ILDAR RAFISOVICH FAKHRADYIEV ${ }^{3}$ \\ ${ }^{1}$ Department of Surgery, Kazakhstan Medical University of Continuing Education, Almaty, \\ Republic of Kazakhstan; \\ ${ }^{2}$ Department of Surgery, State Polyclinic in Central Regional Hospital for Karasaiskii Region, \\ Kaskelen, Republic of Kazakhstan; \\ ${ }^{3}$ Laboratory of Experimental Medicine, Asfendiyarov Kazakh National Medical University, \\ Almaty, Republic of Kazakhstan
}

\section{Summary}

Background: The failure of the intestinal anastomosis remains one of the main problems in gastrointestinal surgery. New principles for solving this problem are focused on the cellular level of regeneration using platelet-rich plasma (PRP). In this study, we evaluated the effect of PRP and experimentally compared the effectiveness of various application methods in intestinal anastomosis regeneration in rabbits.

Materials and Methods: Platelet-rich autoplasma was obtained from 81 rabbits, which we used to study two methods of applying PRP (injection into the muscle layer/soaking in the intestinal wall) in comparison with the control group on the end-to-end small-intestinal anastomosis. We performed a morphological study of intestinal anastomoses after $24,48,72$ hours, and after 7 days. We evaluated the deformation and strength characteristics of the anastomosis on the 7th day.

Results: Analysis of the histological and morphometric data of the study showed that the regeneration between the samples of intestinal anastomosis treated with PRP soaking and injections into the intestinal wall is more favorable in comparison with the control group. The criteria were the quantitative ratio of inflammatory infiltrate, fibroblast proliferation, neoangiogenesis, and collagen deposition. PRP soaking in the intestinal wall significantly increased the number of adhesion conglomerates, which contributed to severe deformation and narrowing of more than $1 / 2$ of the lumen in the intestinal tube. Analysis of the deformation and strength characteristics of the formed anastomoses also showed significantly higher values of the rupture strength of the anastomoses treated with PRP, in contrast to the control group.

Conclusion: PRP soaking and injection into the intestinal wall can have a positive effect on the regeneration of the intestinal anastomosis. PRP injection into the muscular layer of the intestinal wall significantly reduces the development of adhesions in comparison with the PRP-saturated group of intestinal anastomoses. Further research is needed to clarify the optimal method of PRP application, which will improve the regeneration of the intestinal anastomosis.

KEYWORDS: platelet-rich plasma, regeneration of intestinal anastomosis in rabbits. 


\section{UČINAK PLAZME BOGATE TROMBOCITIMA NA REGENERACIJU INTESTINALNE ANASTOMOZE U LABORATORIJSKIH ZEČEVA}

\section{Sažetak}

Uvod: Dehiscencija intestinalne anastomoze je još uvijek jedan od glavnih problema u gastrointestinalnoj kirurgiji. Novi smjerovi istraživanja ovog problema temelje se na staničnoj razini regeneracije korištenjem plazme bogate tromobocitima (PBT). U ovom istraživanju eskperimentalno smo ispitivali učinak različitih metoda aplikacije PBT na zarastanje intestinalne anastomoze u laboratorijskih zečeva.

Materijal i metode: Plazma bogata trombocitima dobivena je od 81 zeca. Ispitivane su dvije metode apliciranja PBT tijekom formiranja termino-terminalne anastomoze tankog crijeva (apliciranjem u muskularni sloj ili natapanjem crijeva) u komparaciji s kontrolom grupom. Učinjena je morfološka analiza intestinalne anastomoze nakon 24, 48 i 72 sata, te nakon 7 dana. Sedmog dana je učinjena evaluacija anastomoze.

Rezultati: Analiza histoloških i morfoloških podataka je pokazala da je regeneracija bila bolja u uzorcima tretiranim $\mathrm{s}$ PBT (u obje ispitivne skupine) $\mathrm{u}$ odnosu na kontrolnu skupinu. To je utvrđeno kvantitativnim odnosom razine upalnog infiltrata, proliferacije fibroblasta, neoangiogeneze, te deponiranja kolagena. U skupini gdje je provedeno tretiranje PBT natapanjem crijeva utvrđeno je više adhezija. Nastali konglomerati adhezija doprinijeli su nastanku deformiteta i sužavanju više od polovine lumena crijeva. Analiza deformacije i izdrzljivosti anastomoza tretiranih s PBT pokazala je njihovu veću otpornost na rupturu u odnosu na kontrolnu skupinu.

Zaključak: Tretiranje crijeva plazmom bogatom trombocitima (natapanjem ili apliciranjem u muskularni sloj crijeva) može imati pozitivni učinak na regeneraciju intestinalne anastomoze. BPT injekcija u mišićni sloj crijeva značajno reducira razvoj adhezija u odnosu na BPT natapanje crijeva. Potrebna su daljnja istraživanja mehanizama regeneracije intestinalne anastomoze i optimalne metode BPT aplikacije.

KLJUČNE RIJEČI: plazma bogata trombocitim, regeneracija intestinalne anastomoze kod zečeva

\section{INTRODUCTION}

Failure of an intestinal anastomosis is an intestinal surgery problem which is not solved yet. However, many studies are aiming to reduce these potentially life-threatening complications (1).

Today, most researchers focus on studying wound regeneration at the cellular level. The platelets are the first blood cells responding to a wound and that they promote tissue regeneration by releasing growth factors and other active agents (2). Growth factors secreted by the platelets are polypeptide molecules with different structures and functions. Platelet-driven growth factor (PDGF), transforming growth factor (TGF- $\beta$ ), vascular endothelial growth factor, fibroblast growth factor (FGF), insulin-like growth factor (IGF) are among the most important once (3). These factors are known for their mitogenic and chemotactic properties, which promote wound healing.

Platelet-rich plasma became widely used in clinical practice because a high concentration of growth factors should promote better tissue regeneration $(4,13,17)$. Despite a large number of studies devoted to PRP effect on intestinal anastomosis regeneration, still, the impact of autoplasma on adhesion and different methods of PRP application is not well established $(5,9)$. As a rule, soaking the intestinal walls with PRP precedes the anastomosis formation $(13,14)$, although injected PRP, which proved to be highly effective in other areas of medicine $(17,18,19,20)$, has not been applied to the intestinal anastomosis.

Regeneration of intestinal anastomosis is undoubtedly a critical process in surgical practice, because a breach in the continuity of the intestinal anastomosis causes wound disruption and, as a result, high morbidity and mortality rate. The first three days are the crucial period to form intestinal anastomosis (6) when the wound is unstable, and the suture suffers from wound-bursting pressure, and it would be helpful to stimulate the regeneration of intestinal anastomosis.

It is in this period when the growth factors secreted by the platelets could play a key role in regulating the migration of the intestinal epithelial cells and anastomosis regeneration.

Many experimental studies dealing with the strength of the formed intestinal anastomoses define wound-bursting strength at an increased intestinal pressure $(5,9,13,14)$. We believe the anastomosis regeneration indicators should be extend- 
ed to measuring the intestinal anastomosis strength with morphometric indicators $(21,22)$. Thus, we carried out experimental research intending to compare the effects of different PRP application methods on intestinal anastomosis regeneration and adhesion development.

\section{MATERIALS AND METHODS}

\section{Laboratory animals}

Eitghty-one laboratory rabbits, chinchillas, used in the research were of different genders, which does not influence the intestinal anastomosis regeneration (24). We used the microsurgical suturing technique for intestinal anastomosis.

The animals were housed in a vivarium at Atchabarov Research Center according to Standard operational procedures for treatment and care of the animals in the postoperative period. The Standard is developed together with the Laboratory of Experimental Medicine.

\section{PRP preparation and activation}

All procedures were performed aseptically at room temperature. Before the anesthesia injection and experiment, we took $8 \mathrm{ml}$ of blood from a peripheral vein in the ear of laboratory animals to PRGF EndoRet (Plasma Rich in Growth Factors from Biotechnology Institute, Spain) test tubes with ACD-A anti-coagulant recommended for PRP-therapy. PRP was prepared using Labofuge 200 centrifuge (Germany) under the test tube instructions from a manufacturer.

We used flow cytometry (ADVIA 120 Hematology System, Bayer) to count the platelets in every PRP sample.

In the $1^{\text {st }}$ group of the laboratory animals, the resected intestinal edges were submerged into activated PRP in a Petri dish for 10 min until PRP solution was completely jellified before suturing the anastomosis.

In the $2^{\text {nd }}$ group of laboratory animals, we injected the muscular layer of the intestinal wall of resected edges circularly with platelet-rich autologous plasma in the amount of $0.2 \mathrm{ml}$ per $1 \mathrm{~cm}^{2}$, before suturing the anastomosis.

In the $3^{\text {rd }}$ group of laboratory animals, we injected the muscular layer of the intestinal wall of resected edges circularly with saline solution in the amount of $0.2 \mathrm{ml}$ per $1 \mathrm{~cm}^{2}$, before suturing the anastomosis.

The animals recovered from the anesthesia: extubation was performed, and animals were transferred to a clean, prepared cages. Ketonal 20 $\mathrm{mg} / \mathrm{kg}$ was administered in the first 24 hours for postoperative analgesia.

The laboratory animals were euthanized with the Almabaev method by administering lethal doses of thiopental sodium and saturated potassium chloride solution IM (Euthanasia methods for laboratory animals in experiments // Patent RK " : 11756// 15.07.2002). The laboratory animals were euthanized randomly depending on the designated observation period by 6 animals in every group. Twenty-one animal was euthanized on the seventh day after surgery by seven animals in each group when we evaluated the woundbursting pressure: once the laboratory animals were euthanized, we performed the relaparotomy, identified the anastomosis and carefully isolated from the adjoining adhesions. We resected a segment of approximately $4 \mathrm{~cm}$ in length with the anastomosis in the middle. The obtained samples were washed with saline solution from feces.

\section{Evaluation of deformation and breaking strength indicators for anastomosis}

The resected segments of the anastomosis were placed in a testing device (Tinius Olsen 1 ST, Redhill, Surrey, UK) with HORIZON app at the distance of $10 \mathrm{~mm}$ between the clamps. The extension rate (Ve) was $5 \mathrm{~mm} / \mathrm{min}$ and was applied continuously. The width of the intestinal wall was $975 \pm 95 \mathrm{mkm}$ on average. The minimal force necessary to induce the anastomosis rupture was recorded as the anastomosis breaking strength. This strength was defined from a force-deformation curve prepared by the application (HORIZON). Before the experiment, the segments were stretched at $0.1 \mathrm{H}$ to apply the force evenly over the anastomosis site, which provides more accurate attachment of the samples to the clamps of the testing device.

\section{Evaluation of adhesions}

Severity and area of the adhesion between the small intestines and abdominal wall were evaluated (Table 1) (7). 
Table 1.

MACROSCOPIC EVALUATION OF ADHESION INTENSITY IN THE ABDOMINAL CAVITY

\begin{tabular}{|l|l|l|l|l|}
\hline Scores & Number of adhesions & Adhesion structure & Adhesion area & Entodermal canal deformation \\
\hline 0 & no adhesion & no & no & no \\
\hline 1 & $\begin{array}{l}\text { one adhesion between the organs } \\
\text { or between organs and abdominal wall }\end{array}$ & membranous & $\begin{array}{l}1 \text { anatomic site } \\
\text { (in our case blind intestine) }\end{array}$ & $\begin{array}{l}\text { Slight deformation without } \\
\text { narrowing of lumen }\end{array}$ \\
\hline 2 & $\begin{array}{l}2 \text { adhesions between the organs } \\
\text { or with abdominal cavity }\end{array}$ & soft, avasculerized & $\begin{array}{l}1 \text { floor of abdominal cavity } \\
\text { (blind intestine + other organs) }\end{array}$ & $\begin{array}{l}\text { Moderate deformation without } \\
\text { narrowing of lumen }\end{array}$ \\
\hline 3 & $\begin{array}{l}\text { More than 2 adhesions between } \\
\text { organs or with abdominal cavity }\end{array}$ & solid, avasculerized & 3 floors of abdominal cavity & $\begin{array}{l}\text { deformation, narrowing of } 1 / 2 \\
\text { lumen }\end{array}$ \\
\hline 4 & Adhesion conglomerate & solid, vascularized & More than 2 floors & $\begin{array}{l}\text { Expressed deformation, } \\
\text { narrowing of more than } 1 / 2 \text { lumen }\end{array}$ \\
\hline
\end{tabular}

The adhesions were evaluated by three independent researchers who had not been informed about the surgical procedure. The obtained data were summarized and averaged for each animal.

\section{Histological and morphological evaluation}

Histological samples of the anastomoses were immediately fixed in $4 \%$ formaldehyde solution. The samples were dehydrated, embedded into the paraffin and cut into $4-\mu \mathrm{m}$ sections, stained with hemotoxylin and eosin (H\&E), and examined by two blinded expert pathologists. The primary purpose of the histological examination was to evaluate the regenerative process along the intestinal suture in three groups in 24, 48, 72 hours, and 7 days after surgery. The evaluation parameters were inflammation intensity (leucocyte infiltration, vascular stasis, clotting, edema), connective tissue formation and structure, the formation of new vessels, joining of intestinal wound edges, presence, and time of epithelization.

Morphological method involves the usage of an application (Image-Pro plus 6.0; Media Cybernetics).

Morphological method examines the following indicators: fiber - crypt index (f/c index), lymphocyte count $(\mathrm{Lm})$, neutrophil count $(\mathrm{Np})$, plasma cell count $(\mathrm{Pc})$, macrophage count (Mph), intraepithelial lymphocyte count (I/e.lm), epithelial-stromal coefficient (e/s), mitosis count in $1 \mathrm{~mm} 2$ outside lymphoid follicles (23).

Animal biological material was disposed of under the procedure for biological waste disposal (These Instructions for biological waste disposal are developed under the subclause $46-11$ of the Article 8 of the Law of the Republic of Kazakhstan as of 10 July 2002 «On Veterinary Medicine»).

\section{STATISTICAL EVALUATION}

A package of statistical software R 3.4.4. for Windows was used for statistical analysis. The arithmetic mean value $(\mathrm{M})$, a standard deviation (SD) were derived from the quantitative indicators. The results are presented as $\mathrm{M} \pm \mathrm{SD}$. Qualitative features were described in absolute (n) and relative values (\%). Variability indexes were calculated. The differences between the parameters under questions were considered to be statistically significant at $\mathrm{p}<0.05$.

Unidimensional variance analysis ANOVA was chosen to be a statistical test. This test assumes that the samples from the groups are independent, and F-distribution is used to test the hypothesis in case of variance analysis. Mann-Whitney U-test (Wilcoxon test) was performed to evaluate the deformation and breaking strength indicators for the anastomoses.

\section{RESULTS}

\section{PRP analysis}

Blood samples taken from the laboratory animals showed a mean hematocrit of $38 \pm 5.4 \%$, a mean leukocyte count of $7.9 \pm 4.110^{3} / \mu \mathrm{L}$, a mean platelet count of $580 \pm 19010^{3} / \mu \mathrm{L}$.

Obtained $8 \mathrm{ml}$ of whole blood yielded a harvest of $0.7-0.8 \mathrm{~mL}$ of PRP, with a mean platelet concentration of $1302 \pm 48010^{3} / \mu \mathrm{L}$. Thus, we managed to achieve a three-fold increase in platelet concentration in comparison with the initial count, leucocyte count in PRP samples was $1.1 \pm 0.610^{3} / \mu \mathrm{L}$. 
Analysis of histological and morphological data

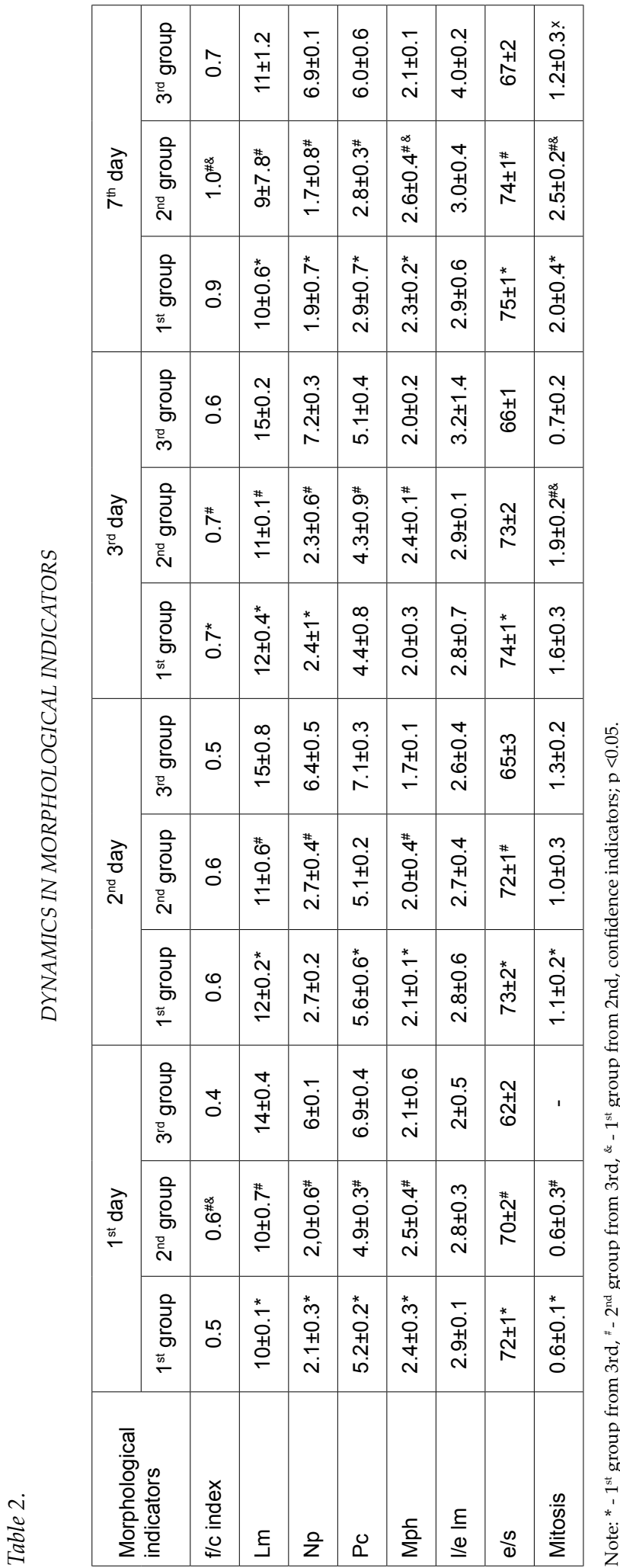

Analysis of the morphological indicators for the $1^{\text {st }}$ and $2^{\text {nd }}$ group of the animals (soaking) revealed the maximum infiltration with the neutrophile leukocytes on the $2^{\text {nd }}$ and $3^{\text {rd }}$ day, by $7^{\text {th }}$ day their concentration decreased by $32 \%$ in comparison with that in the control group. A decline in the specific protective reactions manifested in a decrease of plasma cell count (25) in all groups of the animals was observed on the $3^{\text {rd }}$ day after surgery, although a plasma cell count in the $1^{\text {st }}$ and $2^{\text {nd }}$ groups was lower than in the control group.

A mitosis count in the crypt area is significantly higher in the $2^{\text {nd }}$ group of the laboratory animals on the $3^{\text {rd }}$ and $7^{\text {th }}$ days than that in the $1^{\text {st }}$ and $3^{\text {rd }}$ group, which means their higher capacity for regeneration. Macrophage concentration is significantly higher in the $1^{\text {st }}$ and $2^{\text {nd }}$ group in comparison with the control group during all observation periods, although the $7^{\text {th }}$ day showed significantly higher macrophage concentration in the $2^{\text {nd }}$ group than in the $1^{\text {st }}$ group, which illustrates an extension of the tissue growth area.

Notably, an epithelial-stromal coefficient (e/s) fell in the $3^{\text {rd }}$ group of animals, which correlates with the reduction in the content of epithelial cell count and more connecting tissue deposition.

Lymphocyte count fell on the $3^{\text {rd }}$ day in the $2^{\text {nd }}$ group in comparison with the control group. The $1^{\text {st }}$ group showed less considerable fall in the lymphocyte count on the $7^{\text {th }}$ day.

\section{Macroscopic examination and histology}

All laboratory animals were euthanized at the agreed time; no severe complications or diseases were observed during the experiment. A macroscopic examination of the abdominal cavity in all laboratory animals did not find any failure of the intestinal anastomosis, peritonitis, or any other infection.

The criteria of the adhesion evaluation were applied to evaluate the examination results (Table 3) by three degrees of adhesion intensity:

- 0-4 scores - 1st degree (minor adhesive process);

- 5-10 scores - 2nd degree (moderate adhesive process);

- 10 scores and more - 3rd degree (intense adhesive process). 
Lib Oncol. 2019;47(2-3):55-63

Table 3.

ADHESION EVALUATION

\begin{tabular}{|c|c|c|c|c|c|c|c|c|c|c|c|c|}
\hline & \multicolumn{3}{|c|}{$1^{\text {st }}$ day } & \multicolumn{3}{|c|}{$2^{\text {nd }}$ day } & \multicolumn{3}{|c|}{$3^{\text {rd }}$ day } & \multicolumn{3}{|c|}{$7^{\text {th }}$ day } \\
\hline & $1^{\text {st }} \mathrm{g}$ & $2^{\text {nd }} g$. & $3^{\text {rd }} g$. & $1^{\text {st }} \mathrm{g}$ & $2^{\text {nd }} g$. & $3^{\text {rd }} \mathrm{g}$. & $1^{\text {st }} \mathrm{g}$ & $2^{\text {nd }} g$. & $3^{\text {rd }} g$. & $1^{\text {st }} \mathrm{g}$ & $2^{\text {nd }} g$. & $3^{\text {rd }} g$. \\
\hline Number of adhesion & $2 \pm 1$ & $0 \pm 1$ & $0 \pm 1$ & $4 \pm 2$ & $1 \pm 1$ & $1 \pm 1$ & $4 \pm 2$ & $1 \pm 1$ & $1 \pm 1$ & $4 \pm 2$ & $2 \pm 1$ & $2 \pm 1$ \\
\hline Adhesion structure & $2 \pm 1$ & $0 \pm 1$ & $0 \pm 1$ & $3 \pm 1$ & $0 \pm 1$ & $0 \pm 1$ & $3 \pm 2$ & $1 \pm 1$ & $1 \pm 1$ & $4 \pm 1$ & $3 \pm 1$ & $2 \pm 1$ \\
\hline Adhesion extension & $2 \pm 1$ & $0 \pm 1$ & $0 \pm 1$ & $2 \pm 1$ & $0 \pm 1$ & $0 \pm 1$ & $3 \pm 2$ & $1 \pm 1$ & $1 \pm 1$ & $4 \pm 1$ & $1 \pm 1$ & $1 \pm 1$ \\
\hline $\begin{array}{l}\text { Deformation of } \\
\text { entodermal canal }\end{array}$ & $2 \pm 1$ & $0 \pm 1$ & $0 \pm 1$ & $3 \pm 1$ & $0 \pm 1$ & $0 \pm 1$ & $3 \pm 1$ & $1 \pm 1$ & $1 \pm 1$ & $3 \pm 2$ & $1 \pm 1$ & $1 \pm 1$ \\
\hline Result & $8 \pm 3$ & $0 \pm 1$ & $0 \pm 1$ & $12 \pm 4$ & $1 \pm 1$ & $1 \pm 1$ & $13 \pm 4$ & $1 \pm 1$ & $1 \pm 1$ & $16 \pm 4$ & 4 & 4 \\
\hline
\end{tabular}
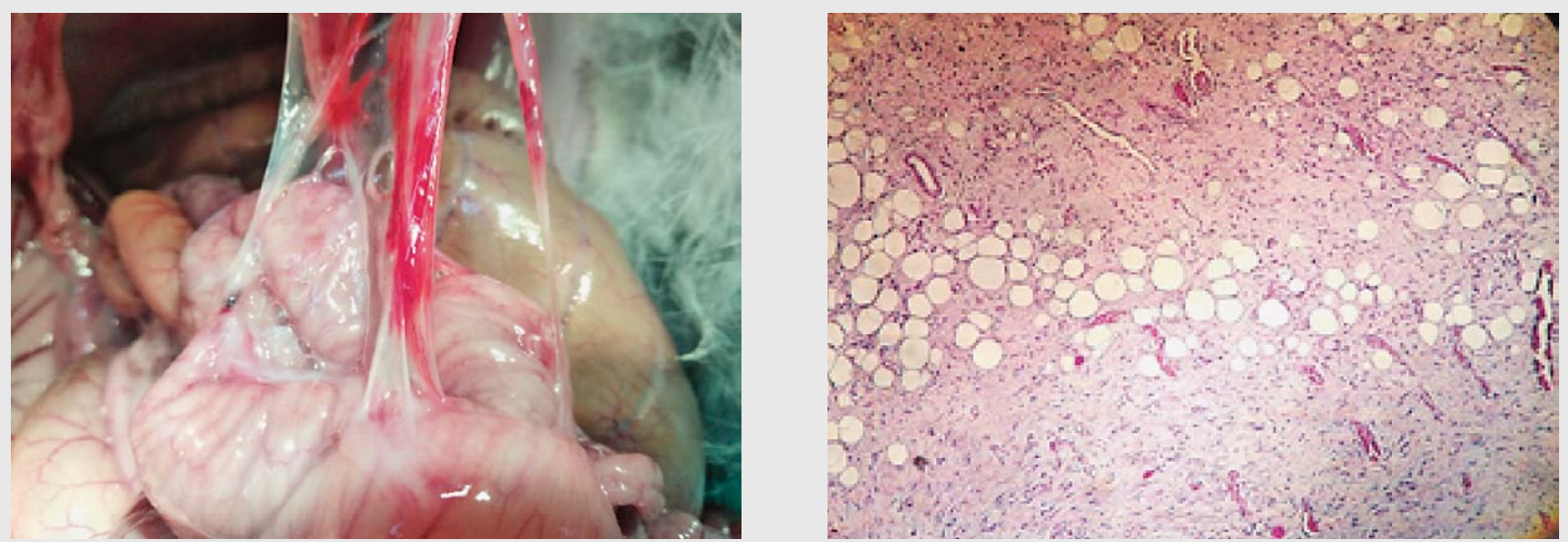

Figure $1.1^{\text {st }}$ group of the laboratory animals (PRP soaking, $7^{\text {th }}$ day).

Extensive adhesive process, vascularized solid adhesions (left). A histological picture of an adhesion. (right) Hematoxylin and eosin staining $\times 20$.
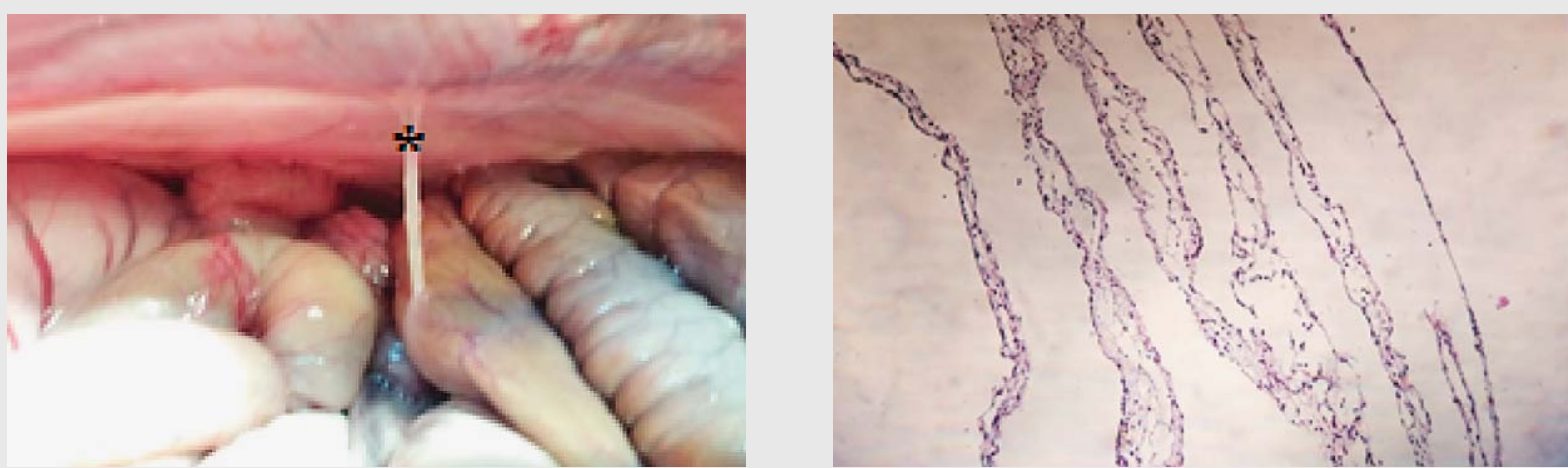

Figure 2. $2^{\text {nd }}$ group of the laboratory animals (PRP injection, $7^{\text {th }}$ day)

Separate, soft adhesions (left). Neoangiogenesis is not found. A histological picture of an adhesion. (right) Hematoxylin and eosin staining $\times 20$.

Adhesion evaluation illustrated that the formed anastomoses treated by PRP (soaking method) in the $1^{\text {st }}$ group of laboratory animals showed the highest degree of adhesion intensity (Figure 1) $(p=0.01)$ in comparison with the anastomoses treated by PRP (injection) in the $2^{\text {nd }}$ group of the laboratory animals (Figure 2 ) and the $3^{\text {rd }}$ group of the laboratory animals (control).

A microscopic evaluation (Table 4) showed significant epithelization of mucosa for the $1^{\text {st }}$ 
Table 4.

A MICROSCOPIC EVALUATION OF THE FORMED ANASTOMOSES

\begin{tabular}{|l|l|l|l|}
\hline Indicators & $\begin{array}{l}\text { PRP soaking. } \\
1^{\text {st }} \text { group }\end{array}$ & $\begin{array}{l}\text { PRP injection. } \\
2^{\text {nd }} \text { group }\end{array}$ & $\begin{array}{l}\text { Control. } \\
3^{\text {rd }} \text { group }\end{array}$ \\
\hline Epithelization & $2.4 \pm 0.4$ & $2.3 \pm 0.5$ & $1 \pm 0.2$ \\
\hline Inflammation & $4 \pm 0.7$ & $3.1 \pm 0.5$ & $3.2 \pm 0.5$ \\
\hline Collagen & $2.3 \pm 0.8$ & $2.2 \pm 0.6$ & $1.9 \pm 0.3$ \\
\hline Fibrosis & $2.2 \pm 0.3$ & $2.5 \pm 0.5$ & $2.0 \pm 0.4$ \\
\hline Neoangiogenesis & $3 \pm 0.7$ & $2.9 \pm 0.8$ & $1.7 \pm 0.2$ \\
\hline
\end{tabular}

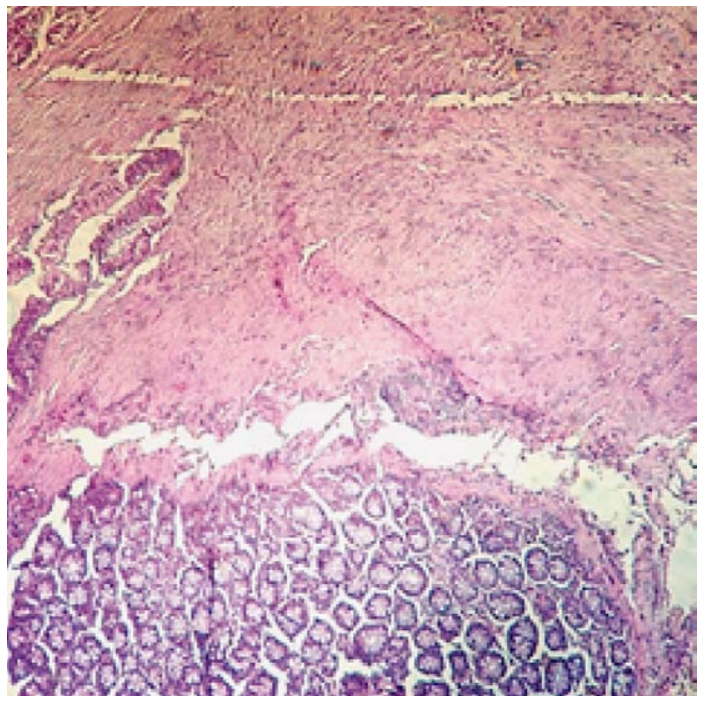

Figure 3. Histological picture of a formed anastomosis on the $7^{\text {th }}$ day. $1^{\text {st }}$ group (PRP soaking). Hematoxylin and eosin staining.

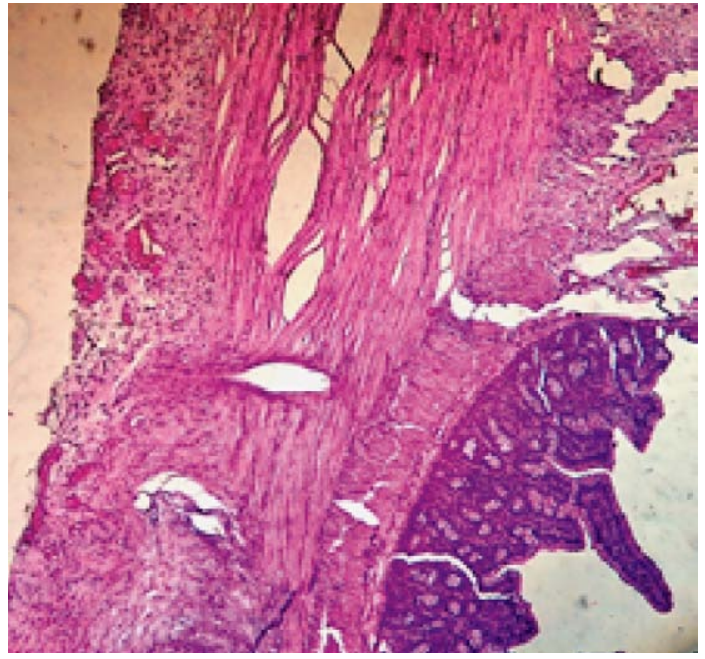

Figure 4. Histological picture of a formed anastomosis on the $7^{\text {th }}$ day. $2^{\text {nd }}$ group (PRP injection). Hematoxylin and eosin staining.
Table 5.

DEFORMATION AND BREAKING STRENGTH INDICATORS

\begin{tabular}{|l|l|l|l|}
\hline Parameters & $1^{\text {st }}$ group & $2^{\text {nd }}$ group & $3^{\text {rd }}$ group \\
\hline Mean & 1.76 & 1.81 & 1.54 \\
\hline Mean square deviation & 0.28 & 0.17 & 0.23 \\
\hline Max & 2.49 & 2.51 & 2.30 \\
\hline Min & 1.32 & 1.30 & 1.17 \\
\hline
\end{tabular}

Mann-Whitney U-test (Wilcoxon test)

group $(\mathrm{p}=0.032), 2^{\text {nd }}$ group $(\mathrm{p}=0.041)$ in comparison with the control group. Neoangiogenesis driven reorganization of the first capillary network is reliably higher in the $2^{\text {nd }}$ group $(p=0.029)$ than in the control group. It should also be noted than no valid differences in an inflammatory infiltrating reaction, collagen and fibrosis formation in comparison with the control group were found.

\section{Analysis of deformation and breaking strength indicators}

A mean value of the deformation and breaking strength indicators (Table 5) for anastomosis rupture in the $1^{\text {st }}$ group was $1.76 \pm 0.28 \mathrm{H}$, in the $2^{\text {nd }}$ group $-1.81 \pm 0.17 \mathrm{H}$, no statistical differences between the two groups were observed $(p=0.69)$ in comparison with the $3^{\text {rd }}$ group (a control group) $1.54 \pm 0.23 \mathrm{H}(\mathrm{p}=0.04)$ and $(\mathrm{p}=0.05)$. A rupture was always within the formed anastomosis sites.

\section{DISCUSSION}

Platelets are the first responders in different injuries of the body and also serve in a therapeutic purposes (8).

Platelet-rich plasma (PRP) is blood plasma with a significant amount of platelets that release the growth factors for wound healing and tissue regeneration. PRP preparation is a procedure with minimal technical costs, and extensive use in stimulating tissue regeneration in different areas of medicine (9).

Activated platelets release more than 300 active agents from their intracellular granules, contain many cytokines, mitogens, anti-inflammatory factors, and other bioactive molecules, which are essential regulators in a complicated microenvironment of the regenerative process, which enhance the healing process. Thus, all components 
necessary for tissue regeneration are concentrated in a wound area.

However, PRP preparation methodology requires special attention, which will definitely be illustrated by further studies.

Despite the benefits from PRP therapy, it has some drawbacks at the preparation and activation stages, as well as at a PRP application stage. In our research, infectious contamination of the anastomosis when the intestinal edges are submerged into PRP solution is difficult to control, which undoubtedly caused additional difficulties during the surgery.

It is important to understand that our knowledge in the area of molecular secretion mechanisms, genetic regulation, and PRP-therapy effects on the regeneration processes is still limited (10). According to available literature, there have been several studies into the PRP effect on intestinal anastomosis regeneration comparing compared PRP soaking in the intestinal walls with PRP injection in anastomosis walls $(13,14)$. Our analysis of the histological and morphometric data also illustrated that regeneration between the intestinal anastomosis sites treated by PRP soaking and PRP injection into the intestinal wall (Table 2) was more favorable in comparison with the control group, which was determined by the quantitative correlation between the inflammatory infiltrate, proliferation of fibroblasts, neoangiogenesis, and collagen deposition (Table 4). The obtained data prove that PRP accelerates the rate and degree of adhesion in a wound (11).

PRP injection (12) in the intestinal wall has more advantages in comparison with the soaking method. Histology did not reveal any fibrosis growth in the injection area, any microangiopathy, and inflammatory process in the $2^{\text {nd }}$ group of the laboratory animals.

Thus, PRP causes cell proliferation and contributes to the synthesis of angiogenic factors during the intestinal anastomosis regeneration, which enhances the healing process independant of the PRP application route.

The present study also evaluates the effects of different PRP application methods on the adhesion process. The obtained data (Table 2) showed that in the group where the PRP soaking was applied (Figure 3), the adhesion process was stronger (a histological picture of an adhesion showed solid vascularized adhesions on the $7^{\text {th }}$ day), in comparison with the control group and the PRP injected group (Figure 4: where membranous adhesions with no signs of neoangiogenesis were found on the $7^{\text {th }}$ day).

The PRP soaking of the intestinal wall formed adhesion conglomerate, which caused the narrowing of more than $1 / 2$ lumen in the intestine. This complication occurs due to many platelets around the formed anastomosis $(15,16)$. The PRP injection in the intestinal avoids this complication.

The analysis of the deformation and breaking strength indicators for the formed anastomoses also showed reliably high values of the breaking strength for the anastomoses treated with the PRP in comparison with the control group. This research illustrated that further studies of different PRP application methods for the intestinal anastomosis could be supported.

\section{CONCLUSIONS}

The PRP application by soaking and injections in the intestinal wall can positively affect the intestinal anastomosis regeneration. The PRP injection in the muscular layer of the intestinal wall reduces the risk of adhesion development in comparison with the PRP soaked group with the intestinal anastomoses.

\section{REFERENCES}

1. Naumann DN, Bhangu A, Kelly M, Bowley DM. Stapled versus handsewn intestinal anastomosis in emergency laparotomy: a systemic review and meta-analysis. Surgery. 2015;157(4):609-18. doi: 10.1016/j.surg. 2014.09.030.

2. Martinez-Zapata MJ, Martí-Carvajal AJ, Sola I, Exposito JA et al. Autologous platelet-rich plasma for treating chronic wounds. Cochrane Database Syst Rev. 2016; 25(5):CD006899. doi: 10.1002/14651858.CD006899.pub3.

3. Estcourt LJ, Malouf R, Hopewell S et al. Pathogen-reduced platelets for the prevention of bleeding. Cochrane Database Syst Rev. 2017;30(7):CD009072. doi: 10.1002/14651858.

4. Marques LF, Stessuk T, Camargo IC et al. Platelet-rich plasma (PRP): methodological aspects and clinical applications. Platelets. 2015;26(2):101-13. doi:10.3109/095 37104.2014.881991.

5. Zhou B, Ren J, Ding C, Wu Y, Chen J, Wang G, Gu G, Li J. Protection of colonic anastomosis with plateletrich plasma gel in the open abdomen. Injury. 2014; 45(5):864-8. 
6. Vil'tsaniuk OA. Ultrastructural description of processes of reparative regeneration in inter-intestinal anastomosis formed by double-row suture method. Klin Khir. 2002;(11-12):16-7.

7. Ayushinova NI, Shurygina IA, Grigoriev EG. Scale assessing the severity of adhesions of the abdominal cavity. Acta Biomedica Scientifica. 2017;6:96-99.

8. Menter DG, Kopetz S, Hawk E, Sood AK, Loree JM, Gresele P, Honn KV. Platelet "first responders" in wound response, cancer, and metastasis. Cancer Metastasis Rev. 2017; 36(2):199-213. doi: 10.1007/s10555017-9682-0.

9. Hattori H, Ishihara M. Feasibility of improving platelet-rich plasma therapy by using chitosan with high platelet activation ability. Exp Ther Med. 2017;13(3): 1176-1180. doi: 10.3892/etm.2017.4041.

10. Golebiewska EM, Poole AW. Platelet secretion: From haemostasis to wound healing and beyond. Blood Rev. 2015;29(3):153-62. doi: 10.1016/j.blre.2014.10.003.

11. Deal JB, Smith E, Heard W. Platelet-Rich Plasma for Primary Treatment of Partial Ulnar Collateral Ligament Tears: MRI Correlation With Results. Orthop J Sports Med. 2017;135(11):2325967117738238. doi: 10.1177/2325967117738238.

12. Charles-de-Sa L, Gontijo-de-Amorim NF. Effect of Use of Platelet-Rich Plasma (PRP) in Skin with Intrinsic Aging Process. Aesthet Surg J. 2018;15;38(3):321-328. doi: $10.1093 /$ asj/sjx137.

13. Giusto $G$ et al. Comparison of the effects of plateletrich or growth factor-rich plasma on intestinal anastomosis healing in pigs. BMC Veterinary Research. 2017; 13:188. doi: 10.1186/s12917-017-1102-8.

14. Fresno L, Fondevila D, Bambo O. Effects of plateletrich plasma on intestinal wound healing in pigs. Vet J. 2010;185(3):322-7. doi: 10.1016/j.tvj1.2009.06.009.

15. Lutsevich OE, Akimov VP, Shirinsky VG, Bichev AA. Adhesive disease of the peritoneum: modern view at pathogenesis and treatment. Khirurgiia (Mosk). 2017; 10:100-108. doi: 10.17116/hirurgia201710100-108.

16. Buţureanu SA, Buțureanu TA. Pathophysiology of adhesions. Chirurgia (Bucur). 2014; 109(3):293-8.

17. Hashim PW, Levy Z, Cohen JL, Goldenberg G. Microneedling therapy with and without platelet-rich plasma. Cutis. 2017;99(4):239-242.

18. Jha AK, Udayan UK, Roy PK. Platelet-rich plasma with microneedling in androgenetic alopecia along with dermoscopic pre- and post-treatment evaluation. J Cosmet Dermatol. 2018;17(3):313-318. doi: 10.1111/ jocd.12394.

19. El-Domyati M, Abdel-Wahab H, Hossam A. Microneedling combined with platelet-rich plasma or trichloroacetic acid peeling for management of acne scarring: A split-face clinical and histologic comparison. J Cosmet Dermatol. 2018;17(1):73-83. doi: 10.1111/jocd.12459.

20. Asif M, Kanodia S, Singh K. Combined autologous platelet-rich plasma with microneedling verses microneedling with distilled water in the treatment of atrophic acne scars: a concurrent split-face study. J Cosmet Dermatol. 2016;15(4):434-443. doi: 10.1111/ jocd.12207.

21. Gerharz M, Baranowsky A, Siebolts U, Eming S, Nischt R, Krieg T, Wickenhauser C. Morphometric analysis of murine skin wound healing: standardization of experimental procedures and impact of an advanced multitissue array technique. Wound Repair Regen. 2007;15(1):105-12.

22. Kustro T, Kiss T, Chernohorskyi D, Chepurnyi Y, Helyes Z, Kopchak A. Quantification of the mandibular defect healing by micro-CT morphometric analysis in rats. J Craniomaxillofac Surg. 2018;46(12):2203-2213. doi: 10.1016/j.jcms.2018.09.022.

23. Sarkisov, D.C., Perov, Yu.L. (Eds.). Microscopic method: Guidelines for doctors and assistants. Moscow: Medicine; 1996.

24. Pickleman J, Watson W, Cunningham J, Fisher SG, Gamelli R. The failed gastrointestinal anastomosis: an inevitable catastrophe? J Am Coll Surg. 1999;188(5): 473-482. doi: 10.1016/S1072-7515(99)00028-9.

25. Wilson RP, McGettigan SE, Dang VD et al. IgM plasma cells reside in healthy skin and accumulate with chronic inflammation. J Invest Dermatol. 2019;29:pii: S0022-202X(19)31623-9. doi: 10.1016/j.jid.2019.05.009.

Corresponding author: Ildar Rafisovich Fakhradyiev, Laboratory of Experimental Medicine, Asfendiyarov Kazakh National Medical University, 94, Tole-bi str., Almaty, 050020, Republic of Kazakhstan. e-mail: fakhradyiev.aknmu@bk.ru 